\title{
A Comparison of Students' Perceptions on Research Methods Pedagogy in Social-Work and Sport Management Courses
}

\author{
Gail M. Augustine, LLMSW, PhD \\ Assistant Professor of Social Work, College of Social Sciences, Arts, and \\ Humanities. Florida A\&M University, Florida, USA \\ Ezzeldin R. Aly, PhD \\ Associate Professor of Sport Management, Department of Health Physical \\ Education and Recreation, College of Education, Florida A\&M University, \\ Florida, USA
}

Doi:10.19044/esj.2020.v16n13p24 URL:http://dx.doi.org/10.19044/esj.2020.v16n13p24

\begin{abstract}
Educators often grapple with the task of teaching a research method course in a manner that would engage and sustain students' attention throughout the semester. The pedagogical dilemma, for the most part, is connecting students' knowledge and attitude to engage in abstract thinking in the research method course appear to be nebulous. The current study aimed to investigate students' perceptions about ethics, values, social justice, and diversity in the research methods curriculum, which will provide frameworks for pedagogical understanding between groups. An understanding by comparing the perception of students will be useful in learning methodology for teaching research-related material on both graduate and undergraduate levels. Sixty graduate and undergraduate students from Florida A \& M University were surveyed to assess their perceptions of ethics, values, social justice, and diversity in three different research method courses. The researchers used the Statistical Package for Social Science (SPSS) to analyze the data and find the outcomes. Data were analyzed using one-way ANOVA to show comparisons between groups in the learning environments with the students in graduate and undergraduate research methods courses. The implications for addressing ethics, values, social justice, and diversity in the research methods were hypothesized.
\end{abstract}

Keywords: College Students, Pedagogy, Curriculum, Diversity, Social Justice, Ethics, Values, Research Methods, Social Work, Sport Management 


\section{Introduction}

At the beginning of the semester, students enter the classroom expressing little or no interest in research method courses. This lack of interest is followed up with poor attendance and less enthusiasm to complete assignments related to research coursework. A plethora of concerns remains about research pedagogies that are related to learners' attitudes towards the requirements and expectations of the research method course. However, the most common lack of interest identified by educators is related to students' anxiety and ambivalence towards research (Bui \& Alfaro, 2011; Hsiao \& Chiang 2011). A plethora of studies have shown evidence of the benefits of research-based learning as it relates to increased student engagement, retention, and academic performance (Jenkins \& Healey, 2010; Sadler \& McKinney, 2010). Research methods or scientific inquiry courses seek to educate students to explore, apply, and produce research and scholarship aimed at advancing professional practice. Students are expected and encouraged to seek out critical thinking, problem-solving, and culturally responsive evidence-based research perspectives, to be used in all of their courses. Also, students are taught methodological approaches in the foundation research methods courses and the advanced evaluation practice course. According to Burke and Rau (2010), by integrating existing research evidence when teaching helps to set the stage for increasing student learning and the use of evidence-based practices (p. 21). Besides, the pedagogical approach upholds evidence-based practice as a building block for scholarship and professional practice. The sense of anxiety and ambivalence that students enter research method courses which are the same for all majors. Students are apprehensive of the material on the research method curriculum, some enter the classroom not knowing what to expect, and others enter the classroom thinking that research is statistics, analytic writing and, computation skills. According to Onwuegbuzie, Leech, Murtoner, and Tahtinen (2005) there is emerging attention for various frameworks for reducing students' anxiety in research method courses. Nonetheless, the challenge of educating the student in higher education to engage in the research method course is constant (Bui \& Alfaro, 2011; Hsiao \& Chiang 2011). Although there is a school of thought, which suggests that the challenges in early collegiate research are often associated with the pervasive negative perceptions and value systems, including perceptions that research is irrelevant, and that pedagogies lack skills in the application of research methods (Dobozy, 2011). The lack of research knowledge and skills, particularly concerning qualitative and quantitative methodologies, but also around analytic writing and computing skills. This study may lead to factors on how educators can address the research pedagogical approach and might help to eliminate the needs of learners in navigating research courses. 


\section{Review of Literature}

The importance of educating students with skills for research methods as part of their undergraduate and graduate degree trajectory is critical. Research methods taught as a degree requirement for a higher education degree, infuse critical thinking, and problem-solving skills for real-life issues. Research methods expose and prepare students to understand social problems and evaluation of programs related to innovation, social change, and progression. The underlying issue is disseminating the research method course in a manner that is engaging and inviting to all learners without inciting anxiety. For the most part, research is about establishing principles that can lead to generalizability, but universality on research pedagogy cannot be formed across disciplines (Lorenz, 2003). Besides, as Howard and Brady (2015) point out, four principles of constructivism to posture in research pedagogy: (1) advance a full understanding of students' pre-existing insights of political science research methods; (2) inspire students to see methodology as an inevitably contested field; (3) offer space for students to choose a methodological style that best aligns with their stance on knowledge; and (4) boost students to view research as an ongoing conversation. The research method is not easily defined or described. Most specifically, the response to this question is as diverse as a large number of books written on the subject of research methods (e. g., Royse, 2018; Rubin \& Barbie, 2016). The dissemination of research method courses varies from university to university. Without a standard approach for defining the research method, this has helped to contribute to the anxiety of students enrolling in research method courses. Engel and Schutt (2017) describe "the nature of the social world as the starting point of social science as a profession because of its response to social, political, and economic conditions" (p. 8). According to Weidman (2010), students are socialized and educated in research concepts through coursework, interactions with professors and peers, and through the practice of conducting independent research. Boitel and Fromm (2014) articulate the research process as characterized by the emphasis on connecting the integration of research to theoretical knowledge and practice. While Banks (2006) asserts that it is life performs and values, as well as the historical and cultural contexts that impact the research process. Given the research process is controlled by students' life stories, socialization, and background on research and scholarship. Consequently, Shulman (2005) infers that research pedagogy is essential to prepare learners to carry out their professional responsibilities with adequate competence and integrity. Therefore, the signature pedagogies across the different discipline's emphasis vary in terms of building competencies and the way learners' cognitive processing in research courses should be shaped. For instance, law, sports management, nursing, and social work disciplines are 
more likely to have a variety of focus in the dissemination of research courses. Shulman (2005) claimed that the dissimilarities in the signature pedagogies across the different disciplines are distinguished by the attention that is given in three dimensions, including thinking, performing, and acting with integrity.

\section{Law Signature Pedagogy}

Coughlin, McElroy, and Patrick (2009) characterized dimensions of research learning across discipline as a function that is disseminated to influence the way learners need to think within a given major. Socratic case deduces a pedagogical approach that focuses on educating learners with an analytic understanding of the legal processes and the ability to discern the opposing sides of a legitimate argument (Dickinson, 2009). This approach is mainly used in the law research method course and is demonstrative in law students being taught and trained on how to think analytically. In this instance, the emphasis is on the learners' cognitive ability being informed by an on par with the Socratic case dialogue teaching approach, which is the signature pedagogy in most legal education (Mertz, 2007). The Socratic Method grounded law teaching in a scientific approach, which in turn gained it increased prestige (Kimbell, 2004 cited in Abram, 2015, p. 565). Shulman (2005) in support to this approach, highlighted that students are educated with the ability to identify facts relating to pre-existing knowledge and to imply legal expression, On the other hand, Madison III (2009) points out that law signature pedagogy focuses primarily on the preparation of the learners to think like lawyers, yet it fails to prepare students on how to perform proficient skills and does little to integrate integrity and social skills. Thus, this approach, in its persistence, has exerted mixed reactions in academia on its effectiveness in providing efficiency in learners' empirical aptitude.

\section{Sports Management Signature Pedagogy}

In 1987 the fundamental of Sport Management education was established by the National Association for Sports and Physical Education (NASPE) and the National American Society of Sport Management (NASSM) (Jones, Brooks \& Mak (2008) cited Zhang, Wang, Min, Chen \& Huang, 2016). The NASPE and NASSM formulated the standards and the quality of pedagogy, and coursework proficiencies. Some studies point to the servicelearning or experiential learning course as the signature pedagogies in sports management education (Valerius, Keller, Doyle \& Collins, 1998; Gregg, 2003). Gregg (2003) describes experiential learning as the pathway for learners connecting theoretical knowledge with a practical application of sports management classroom concepts. Sports management profession emphasizes research in the field of sports as a means through which students gain the necessary skill-set to perform and to compete like the professionals 
in the real world. The importance of students engaging in research method courses in sports management programs encompasses the requirements of competencies needed for graduates of higher education matriculation. According to (Susan, el, 2009) In 2008, NASPE and NASSM collaboratively established the Commission on Sport Management Accreditation (COSMA), and the purpose of COSMA was to encourage and distinguish excellence in sport management education universal in colleges and universities at the baccalaureate, masters and doctoral levels. Sport management curriculums, students, managers, and the general public all benefit from the exterior authentication of excellence through COSMA's accreditation process. They are also promoting superiority in sport management education. Accordingly, the underlying assumption of the current study is that participation in research method courses can be beneficial to all students beyond the classroom. In developing students' proficiencies during their matriculation, the opportunity to integrate research knowledge into service-learning experiences becomes critical for students' overall success. Thus, sports management literature is replete with instances of research that inform practice.

\section{Nursing Signature Pedagogy}

Shulman (2005) provides a rationale for the importance of clinical experiences as its signature pedagogies in the nursing discipline. More specifically, experiential learning has been identified as an essential aspect of nursing signature pedagogy (Lisko \& O'dell, 2010). To adequately impart competence and care to learners, nursing education has espoused multiple signature pedagogies, which include experiential. As is the case with nursing, the education profession is characterized by various signature pedagogies. More specifically, Crippen and Archambault (2012) assert that signature pedagogy in science education is the inquiry-based instruction that prepares the learners to think and perform like a scientist. This approach encompasses the cognitive aspect, practice skills, and values that are important for nursing research progression. Learners are engaged in possible solutions and scientific ways of addressing the identified problem within the nursing discipline throughout the research process.

\section{Social Work Signature Pedagogy}

According to the arguments made by Shulman (2005) and the interpretation provided by the Council on Social Education (CSWE) 2015 Educational Policy and Accreditation Standards (EPAS), the signature pedagogy in social work education, is field practicum (Petracchi \& Zastrow, 2010). Field practicum allows learners to engage in experiential learning to adopt social work values and ethics in real-life settings. However, as mandated by CSWE 2015, the social work curriculum must enable learners to "involve 
in practice-informed research and research-informed practice" (CSWE, 2015, p.8). Most disciplines have alluded to specific characteristics as their signature pedagogies. For social work, learners must connect research and theoretical knowledge to produce evidence-based knowledge in field education. As such, empowering students to engage in research and experiential learning as professionals. In social work, the duality of signature pedagogy alludes to both an evidence-based and research-informed aspect of the curriculum. According to Rowan, Richardson, and Long (2018) referred to the dichotomy of social work profession when explaining the dual relationship between practice and research. They stated that "practitioners rely upon researchers to identify best practices, evaluate the effectiveness of interventions and programs, the human document need, and advocate for change" (p.15). Similarly, to another profession, social work relies on research to produce "valued insight about emerging issues, needs of populace groups, and the efficacy of interventions" (p.15). Rubin and Babbie (2007) that social workers employ the best scientific knowledge to intervene with individuals, families, groups, organizations, and communities. The need for research in the social work profession cannot be undermined as a signature pedagogy. Also, research class is offered late in the curriculum rather than infused into each class throughout matriculation, resulting in anxiety when introduced. Students should be able to engage in research during their experiential learning with a level of competency, providing a reasonable basis for those experiences before entering the professional world. Research method pedagogies is to build up relevant knowledge and capabilities by developing critical intellectual principles and aptitudes. Therefore, students must be stimulated to engage in inquiries and knowledge-producing based on the continuum of learning values, ethics, and diversification on real-world issues.

\section{Lecture Stimulation Engagement}

Educating students in the research course requires lecture stimulation with the method of dissemination and the content connected to the individual course competence or learning outcome. Linneman (2019), in a study, examine active learning lecture format delivery on a sample of 266 students in nine sections a of research method that was taught by one specific instructor. Linneman found that the differences in course delivery were a determinant of students' performances. Students' performances were more favorable in lecture stimulation discourse and were more effective than lecture-only delivery. In a research course, students tend to prefer lecture driven delivery. More specifically, Howard and Brady (2015) characterize lecture stimulation in the research course as necessary, stating that this linkage must encompass a critical engagement with the learner to ensure education on research content and other value related to the specific discipline. Linneman (2019) contends 
that the instructor's philosophical stance has a cogent impact on the teaching and method of delivery leading to the learners' performances. Some studies indicate that performance-focused classrooms can cause students to question their ability or the ability of their social group, thereby evoking schemas or stereotypes about the group (Steele, 1997). Frisby (2005) echoes the need for an increase in social science pedagogical strategies to "healthy foster debate, critique, and social justice" (p.8). Given the evaluation of the research method, the classroom climate is of importance to influence critical engagement.

\section{Critical Engagement}

At the beginning of the semester, critical thinking is present; the learners have read the syllabus, which had informed them of the research method process. They have to establish now the research method course syllabus to understand that the research method syllabus is not like the other course syllabi. The syllabus must have a clear message that the primary assignment is a customized research project encompassing, values, ethics, and social justice issues relating to real-life issues. The objective is to give the learner a chance to provide the reader with a creative idea and to engage in evaluating the limitation and further recommendation for a real-life concern. This process suggests that it is not a matter of asking what kind of cognitive processes and conceptual structures that learners are involved in, but what kinds of critical engagements pedagogy provides within the appropriate context for learning to take place. Johnstone and Soares (2014) emphasize the importance of delivery style to build the learners' competency. They contend that it is the pedagogical method that is directly responsible for the learning process towards the perceptible mastery and application of the theory and practical development of the learner. By promoting student-centered learning, competency-based education also facilitates students to be accountable for their progress. Hence, engagement tends to activate and increase learning on every level. However, in any given classroom in higher education involvement is not easily attainable. The following theoretical framework presentation highlights the negotiation of learning and cognitive processing in the higher education community.

\section{Situated Learning}

Situated learning theory was introduced by Lave and Wenger (1991) and assumes that the epistemological framework is socially and culturally constructed. Lave and Wenger (1991) characterized a community of practice as" a set of relatives between persons, commotion, and the world over time and in relation with other tangential and intersecting groups of practice" (p. 98). These theorists suggest that peripheral participation is required for both the development of knowledgeability of skilled identities in practice and the 
reproduction and transformation of communities of practice. Situated learning theory was selected as the theoretical framework because of its relevance to informal learning in multifaceted social systems in both sports management and social work courses. Knowles (1984) emphasizes the importance of a classroom climate that accommodates the learners' feelings as a critical factor for students' learning ideas in a research course. The current study investigates research method course content and delivery that focuses on learners' attitudes towards an exploration of social, cultural, economic, and political issues as it relates to their major. Of particular interest, the current study explored students' interests in diversity and social justice variables in research methods in three different courses. According to Lave and Wenger (1991) learning usually involves multiple levels of participation, ranging from core group, active, peripheral, occasional, and transactional. Lave and Wenger (1991) contend that at the core group participation level, a relatively small group of learners are involved in this level in the learning community. During the active participation level, learners are defined as the community, although they may not be of one mind as to the objective of the learning community. Within this orientation, the occasional learners only participate when the topic is of particular interest when they have some specific contribution involving in a project related to the domain of the community. For the outlying learners is connected to the community with less engagement because they do not have a vested interest in the learning process. Transactional participants are learners who are distant holding an outsider's level and only interacting occasionally in the community (Lave \& Wenger, 1991). Wenger (1998) contends that at the core group participation level relatively small group of learners are involved in this level and develop the learning community. During the active participation level, learners define the community, although they may not be of one mind as to the objective of the learning community. The occasional learners only participate when the topic is of particular interest when they have some specific contribution involving a project related to the purview of the community. For the peripheral learner's sustainability is connected to the community, but with less engagement, as onlookers without any commitment to the learning process.

The transactional learner is distant from the learning arena and holds an outsider's posture interacting occasionally but not fully invested in the community (Wenger, 1998). Situated learning theory has been used in considering research method learners' classroom experiences as they decrease anxiety and develop intellectual aptitude in research method courses. More specifically, the conceptual orientation points to how learners can check-in and out of classroom research methods discourse in the learning arena throughout the semester for a plethora of reasons. Whether checking in or out physically, mentally, and intellectually, this level of disengagement can 
impede learning and knowledge production. Herein lies the concerns for pedagogical approaches which be all engaging for the various types of learner in reach classrooms. From a critical engagement approach, it not so much that research learners receive a passing grade in the course; it is necessary for learners to proliferation an understanding of the research process. The critical engagement pedagogy process requires learners to be actively involved in the research method process as situated learning. Wenger (1998) contends that this type of learning encompassing the process of active participation in the learning community while constructing a research-minded identity.

\section{Methodology}

The authors surveyed a convenience sample of students during the spring semester of a class of undergraduate and graduate levels of research methods classes. The authors specifically requested that the survey be distributed before the students receiving the syllabus or any other course materials that might produce anxiety so that knowledge of variable course components (e.g., number of exams, final papers, oral presentations, etc.) would not affect student responses. In total, the survey was distributed to sixty students in three different classes, two of which were graduate-level classes, and one was an undergraduate class. The two types of classes surveyed were social work research methods and sport management research seminar. The introductory course exposes students to research methods by requiring them to read empirical studies and is designed to prepare students for advanced research seminar course, which focuses on designing both quantitative and qualitative research studies. Response rates for the in undergraduate class was $94 \%$; for one graduate-level class response rate was $100 \%$, and the other response rates were significantly lower at $40 \%$. The overall survey response rate was $80 \%$. Data Analysis; Data analysis reported strategies for creating a pedagogical approach for connecting students of various backgrounds and disciples in research method courses. Data were analyzed using one-way ANOVA to show comparisons between groups in the learning environments with the students in graduate and undergraduate courses. The implication for addressing ethics, values, social justice, and diversity when unpacking research methods course contents are hypothesized to provide a better understanding of pedagogical approaches when disseminating research method courses. In this paper, we examined the differences between students in social work and sports management towards research.

\section{Results and Discussion}

Survey components of eight questions that query the intrigue of the students towards research and their desire to address issues. The next set of questions are on how the students felt towards the research methods class. Also, 
twenty-three questions are on ethics and values in research. The answers for each question ranged from strongly-disagree to strongly-agree. Before modeling the relationship, researchers test whether the combination of different questions correlates with creating an additive index. To estimate the internal consistency of these question groupings, we estimate Cronbach's alpha for each group of questions, which will measure the reliability of the scale. Reliability, in this case, refers to how well the questions measure the underlying concept. A general rule of thumb is a Cronbach's alpha above 0.7 indicates a strong relationship between the set of questions. An advantage of using Cronbach's alpha is that it can determine empirically whether the coding of some questions will have to be reversed to improve reliability. A reverse coding, in this case, would likely occur because a question where, for example, a "No" answer would be a positive view is then in the opposite direction of questions where a "Yes" refers to a positive to allows higher values of the scale to represent more productive uses of time and for responses that are coded as "not sure" to have no impact on the scale's values. Also, Cronbach's Alpha will drop questions where there is no variation in the answers given by respondents because it cannot calculate the inter-item correlation.

Table 1: Below displays the Cronbach's alpha for the three variable groupings.

\begin{tabular}{|c|c|c|}
\hline & Social Worke & Sports Mgt. \\
\hline Research interest & 0.82 & 0.60 \\
\hline Research methods pportunities & 0.84 & 0.95 \\
\hline Research ethics and values & 0.94 & 0.73 \\
\hline
\end{tabular}

Table 1: Standardized Cronbach's Alpha by Student Major

From the table above, researchers can see that there is nearly significant internal consistency across the three measures by both types of students. However, for students of sports management, some of the questions were reversed to construct an index. For the research interest question (i.e. questions 7.1 - 7.8), questions relating to care in sports management were negatively correlated to interest in overall challenges. The final set of questions that had some reverse coding were those related to values and ethics in research (i.e. questions 9.1 - 9.23). However, the interesting issue is that the reverse coding only occurs for students in sports management. Furthermore, the questions that were reversed depict an exciting picture of how sports management students feel about the research process. Although all questions are designed where a higher value denotes more confidence in the research process, students of sports management seem to be less confident in professionals of their field than social work students. For example, questions that relate to ideological priorities and professional researchers being objective and competent were reversed $(9.4,9.6,9.9,9.11,9.12,9.22,9.23$, and 9.18). The result revealed some hesitation by the students to trust research methods. To test whether there are differences in the questions related to research 
methods by student majors, the researchers calculated the total scores for each principal across the scales. Once we calculated the scores, we determined that the appropriate test to conduct was a difference of means test. This test will indicate whether scores differ across each major. However, before conducting each test, researchers determine what type of test is best suited for the data. The usual difference of means test is conducted using a t-test to determine whether the means of each group differs, but this model requires that both groups be normally distributed and have equal variance. When the variances are unequal a Welch's t-test can be conducted and is more reliable when the two samples have unequal variances and unequal sample sizes. When distributions are non-normal then we would have to use a Wilcoxon Rank Sum Test, which was described as the non-parametric version of the two-sample t-test. However, this test requires that the samples have equal variance. Also, the interpretation of the test is different from a difference of means test. This study hypothesized distributions are equal, rejecting the null means indicated that the medians of the two populations differ — the quantile-comparison plot with $95 \%$ confidence intervals for each variable. The plot demonstrated whether the distribution of the data follows a normal distribution, which was reflected in a considerable number of points falling outside of the confidence intervals. A quantile-comparison plot for the Research Interest index split by major in Figure 1. Also, distributions appear to be normally distributed.

Figure 1: Quantile-Comparison Plot of Research Interest by Major

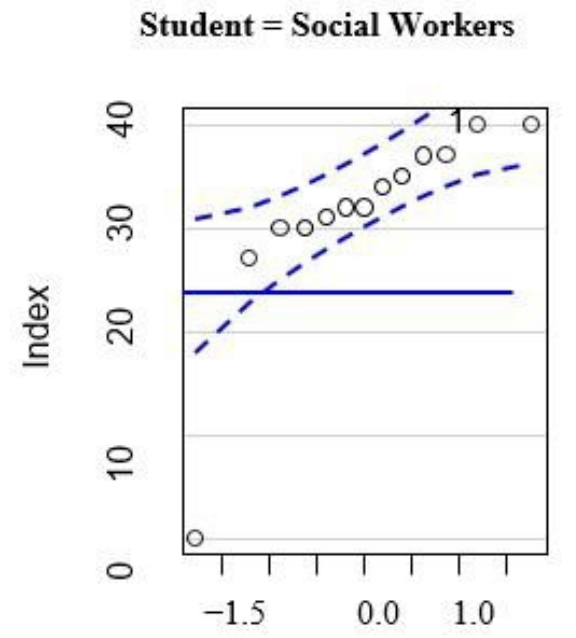

Normal Quantiles
Student $=$ Sport Mgt .

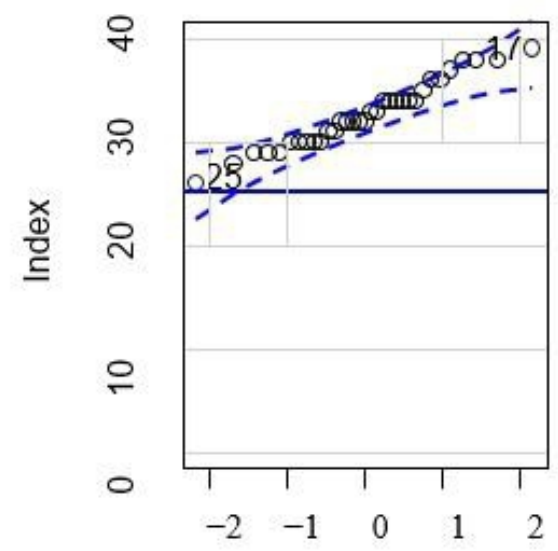

Normal Quantiles

The next test to conduct is to determine whether the variances are equal. We used two types of tests to ensure a robust result. First, we used a Levene's test to determine whether there is equal variance across samples. However, Levene's test assumes that both samples are approximately standard. Second, 
we used a Fligner-Killeen test, which is a non-parametric test, to determine whether the samples originate from the same distribution also used for comparing two or more independent samples of equal or different sample sizes. For both tests rejecting the null hypothesis indicates that there is unequal variance across both groups. The results in Table 1 cannot reject the null hypothesis that the variances are not equal.

Table 2: Equal Variance Tests for Research Interest Index

\begin{tabular}{|c|c|}
\hline Levene's Test & 0.056 \\
\hline Fligner-Killeen Test & 0.119 \\
\hline
\end{tabular}

To create a robust test of the difference between both these groups, researchers conducted a t-test and a rank-sum test. This recent study found that there is no statistical significant difference between students of social work and sports management on their interest in conducting research.

Table 3: Tests for Research Interest Index

\begin{tabular}{|c|c|c|}
\hline & T-test & Rank Sum Test \\
\hline Average Difference & -0.804 & 226.500 \\
\hline P-Value & 0.426 & 0.778 \\
\hline
\end{tabular}

\section{Research Methods Learning Index}

The next orientation score of interest is the research methods learning index. To conduct the analysis, we proceed with the similar steps outlined in the previous section.

Figure 2: Quantile-Comparison Plot of Research Methods Learning Index by Major

Student $=$ Social Workers

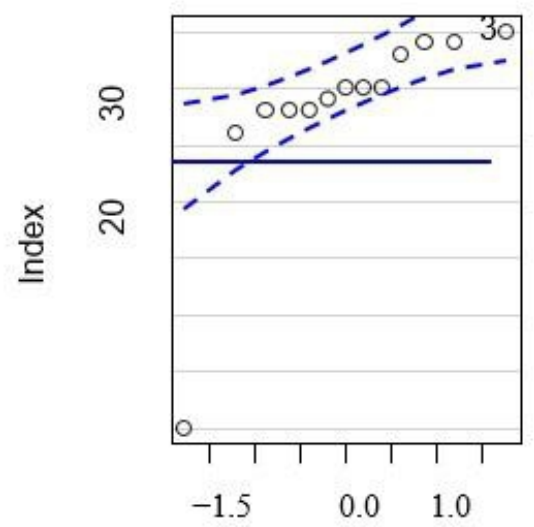

Normal Quantiles
Student $=$ Sport Mgt.

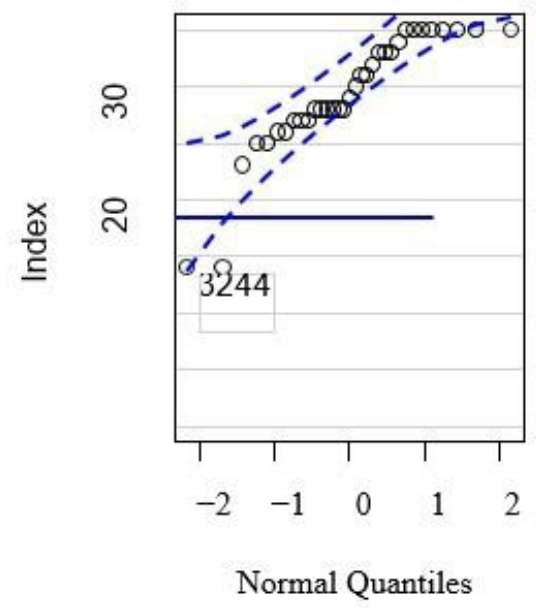

Again, aside from a few outliers, the results appear to be normally distributed, and the variance of both groups do appear to be equal. 
Table 4: Equal Variance Tests for Research Methods Learning Index

\begin{tabular}{|c|c|}
\hline & P-values \\
\hline Levene's Test & 0.860 \\
\hline Fligner-Killeen Test & 0.300 \\
\hline
\end{tabular}

After conducting a Two-Sample t-test, we find that there is no statistically distinguishable difference in the means of both groups on Research Methods Learning. Even when conducting a non-parametric test, the results still hold, demonstrating that there is no statistically distinguishable difference between the groups.

Table 5: Tests for Research Methods Learning Index

\begin{tabular}{|c|c|c|}
\hline & T-test & Rank Sum Test \\
\hline Average Difference & -0.588 & 214.500 \\
\hline P-Value & 0.560 & 1 \\
\hline
\end{tabular}

\section{Values and Ethics Index}

The third orientation score of interest is the Values and Ethics Index. To conduct the analysis, we proceed with the similar steps outlined in the previous section.

Figure 3: Quantile-Comparison Plot of Values and Ethics Index by Major

Student $=$ Social Workers

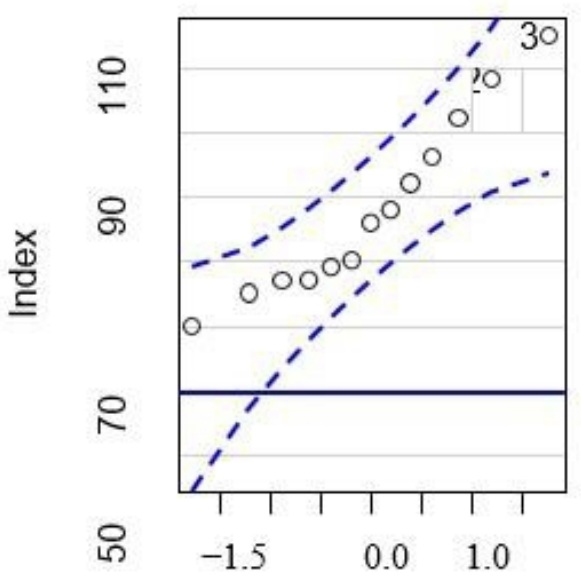

Normal Quantiles
Student $=$ Sport Mgt.

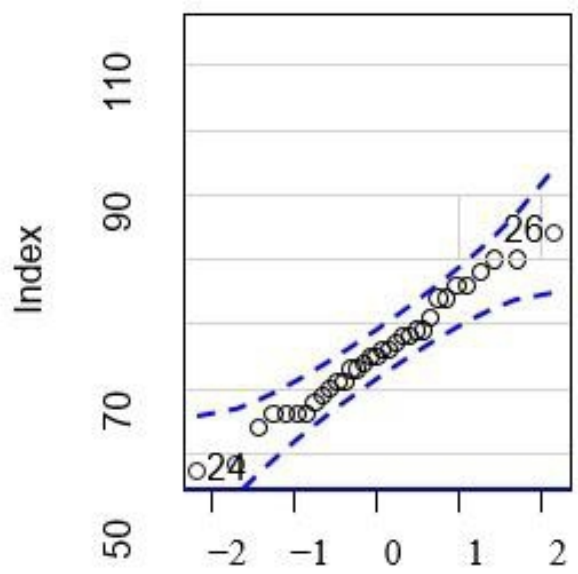

Normal Quantiles

The results appear to be normally distributed, and the variance of both groups do appear to be equal.

Table 6: Equal Variance Tests for Values and Ethics Index

\begin{tabular}{|c|c|}
\hline P-values & \\
\hline Levene's Test & 0.074 \\
\hline Fligner-Killeen Test & 0.096 \\
\hline
\end{tabular}


After conducting a Two-Sample t-test, we find that there is a statistically Table 8: Participants from both social work and sport management majors were evaluated on a series of questions to determine the importance that they placed on ethics and values. Results indicated that distinguishable differences in the means of both groups on Values and Ethics Index in both a parametric and non- parametric test. In fact, according to the difference in the means test, students in sports management score about 23 points less than students in social work. These findings highlight their hesitance towards trusting social research, indicating that social work students are more likely to perceive and to trust research outcomes as an evidence-based practice.

Table 8: Test for Values and Ethics Index

\begin{tabular}{|c|c|c|}
\hline & T-test & Rank Sum Test \\
\hline Average difference & 6.519 & 401 \\
\hline P-Value & 0.000 & 0.00001 \\
\hline
\end{tabular}

Results indicated that $55 \%$ of a participant is social work significant and $42 \%$ sport management major.

Table 9: Participant Ethnicity

\begin{tabular}{|c|c|c|c|c|}
\hline & Frequency & Perecent & Valid Percent & $\begin{array}{c}\text { Cumulative } \\
\text { percent }\end{array}$ \\
\hline White/Caucasian & 10 & 21.3 & 21.3 & 21.3 \\
\hline $\begin{array}{c}\text { African } \\
\text { American/Black }\end{array}$ & 31 & 66.0 & 66.0 & 87.2 \\
\hline South Asian & 3 & 6.4 & 6.4 & 93.6 \\
\hline Middle Eastern & 2 & 4.3 & 4.3 & 97.9 \\
\hline Puerto Rican & 1 & 2.1 & 2.1 & 100.0 \\
\hline Total & 47 & 100.0 & 100.0 & \\
\hline
\end{tabular}

Table 9: Results indicated that participants are 21\% Caucasian, 66\% African American, and 6.4\% South Asian, 4.3\% middle eastern, and $2.1 \%$ Puerto Rican Participant $40 \%$ undergraduate level and $60 \%$ graduate level

Table 10. Tolerance working with others

\begin{tabular}{|c|c|c|c|c|}
\hline Validity & Frequency & Percent & $\begin{array}{c}\text { Valid } \\
\text { Percent }\end{array}$ & Cumulative Percent \\
\hline & 2 & 4.3 & 4.3 & 4.3 \\
\hline 3 & 5 & 10.6 & 10.6 & 14.9 \\
\hline 4 & 19 & 40.4 & 40.4 & 55.3 \\
\hline 5 & 21 & 44.7 & 44.7 & 100.0 \\
\hline & 47 & 100.0 & 100.0 & \\
\hline
\end{tabular}

Table 10: Results indicated that $44 \%$ of the participant strongly agreed that they have Tolerance of others with different beliefs and $40 \%$ of the participant agreed that they have tolerance of others with different beliefs, only $4.3 \%$ disagreed that they have tolerance of others with different beliefs. 
Table 11: Critical thinking skills

\begin{tabular}{|c|c|c|c|c|}
\hline Validity & Frequency & Percent & $\begin{array}{c}\text { Valid } \\
\text { percent }\end{array}$ & Cumulative percent \\
\hline 3 & 7 & 14.9 & 14.9 & 14.9 \\
\hline 4 & 25 & 53.2 & 53.2 & 68.1 \\
\hline 5 & 15 & 53.2 & 53.2 & 100.0 \\
\hline & 47 & 100.0 & 100.0 & \\
\hline
\end{tabular}

Table 11; Results indicated that $31 \%$ of the participant strongly agreed that critical thinking skills is essential competent for research, $53 \%$ of the participant agreed that critical thinking skills is an essential factor for research.

Table 12: Ability to work cooperatively with diverse people

\begin{tabular}{|c|c|c|c|}
\hline Frequency & Percent & Valid percent & Cumulative percent \\
\hline 1 & 2.1 & 2.2 & 2.2 \\
\hline 17 & 36.2 & 37.0 & 39.1 \\
\hline 28 & 59.6 & 60.9 & 100.0 \\
\hline 46 & 97.9 & 100.0 & \\
\hline 1 & 2.1 & & \\
\hline 47 & 100.0 & & \\
\hline
\end{tabular}

Table 12; Results indicated that $97 \%$ of the participant they can work cooperatively with diverse people, only $2.1 \%$ of the participant they disagreed that they can work cooperatively and diversely with people.

Table 13: Colleges have the right to ban extreme speakers from campus

\begin{tabular}{|c|c|c|c|c|}
\hline Validity & Frequency & Percent & Valid percent & Cumulative percent \\
\hline 1 & 2 & 4.3 & 4.3 & 4.3 \\
\hline 2 & 12 & 25.5 & 25.5 & 29.8 \\
\hline 3 & 16 & 34.0 & 34.0 & 63.8 \\
\hline 4 & 12 & 25.5 & 25.5 & 89.4 \\
\hline 5 & 5 & 10.6 & 10.6 & 100.0 \\
\hline $\mathrm{T}$ & 47 & 100.0 & 100.0 & \\
\hline
\end{tabular}

Table 13; results indicated that only $10 \%$ agreed that colleges have the right to ban extreme speakers from campus, and $84 \%$ of the subjects disagreed that colleges have the right to ban extreme speakers from campus.

Table 14: Colleges should prohibit racist/sexist speech on campus

\begin{tabular}{|c|c|c|c|c|}
\hline Validity & Frequency & Percent & Valid percent & Cumulative percent \\
\hline 1 & 4 & 8.5 & 8.7 & 8.7 \\
\hline 2 & 4 & 8.5 & 8.7 & 17.4 \\
\hline 3 & 13 & 27.7 & 28.3 & 45.7 \\
\hline 4 & 7 & 14.9 & 15.2 & 60.9 \\
\hline 5 & 18 & 38.3 & 39.1 & 100.0 \\
\hline Total & 46 & 97.9 & 100.0 & \\
\hline System & 1 & 2.1 & & \\
\hline Total & 47 & 100.0 & & \\
\hline
\end{tabular}


Table 14: results indicated that $38 \%$ of the participant strongly agreed to colleges should prohibit racist/sexist speech on campus, and $41 \%$ agreed to colleges should prohibit racist/sexist speech on campus; also $17 \%$ of the participant disagreed on the prohibit of racist/sexist to speech on campus.

Table 15: Women should receive the same salary and opportunities for advancement as men in comparable positions

\begin{tabular}{|c|c|c|c|}
\hline Validity & Percent & Valid percent & Cumulative percent \\
\hline 1 & 2.1 & 2.1 & 2.1 \\
\hline 2 & 4.3 & 4.3 & 6.4 \\
\hline 1 & 2.1 & 2.1 & 8.5 \\
\hline 5 & 10.6 & 10.6 & 19.1 \\
\hline 38 & 80.9 & 80.9 & 100.0 \\
\hline 47 & 100.0 & 100.0 & \\
\hline
\end{tabular}

Table 15 Results indicated that $91 \%$ agreed that women should receive the same salary and opportunities for advancement as men in comparable positions and $6 \%$ disagreed that women should receive the same compensation. Participants were asked whether women should receive the same salary and opportunities for advancement as men in comparable positions. Results indicated that $91 \%$ agreed that women should receive the same salary and opportunities for advancement as men in comparable positions and $6 \%$ disagreed that women should receive the same compensation. On critical thinking question Results indicated that $31 \%$ of the participant strongly agreed that critical thinking skills is essential competent for research, $53 \%$ of the participant agreed that critical thinking skills is an essential factor for research. According to Meltzoff and Cooper (2018) to become an informed, interactive consumer of research, students may need an attitude alteration: from acceptance to inquiry, from reverence to skepticism. Critical thinking about research: social science and related fields equip you with those tools needed to identify errors in others' research and to lower them to a minimum in student's work. In another study by (McGarth et al., 2003) about critical thinking and research found that critical thinking influences research effectiveness; however, empirical support for the link between critical thinking dispositions and research utilization is nonexistent. Also, indicate a significant positive correlation between the total critical thinking disposition score and overall research utilization. Overall critical thinking qualities correlate significantly with all forms of research utilization, except for symbolic research utilization. These findings indicated a need to foster critical thinking qualities in both nursing education and the work environment.

\section{Conclusion}

There are several similarities and differences with how students across disciplines view research method courses. The allegiance and commitment 
that students hold towards research methods weighs heavily on getting students to understand research values, ethics, social injustice and diversity as it relates to social problems in the real world. As such the curriculum and pedagogical dissemination must encompass components that embraces the engagement of students that holds their interest throughout the semester. Research method pedagogy must solicit the full engagement of students beyond the traditional or conventional style of teaching discourse. Bourdieu (1992, p. 222) argues, exposing learners to the realities of social research therefore 'requires a pedagogy which is completely different from that suited to the teaching of knowledge': ... there is no better manner of mastering the fundamental principles of a practice - the practice of scientific research is no exception here - than by practicing it alongside a kind of guide or coach who provides assurance and reassurance, who sets an example and who corrects you by putting forth, in situation, precepts applied directly to the particular case at hand.

\section{References:}

1. Alemanne, N. D., \& Mandel, L. H. (2018). Developing Research Practitioners: Exploring Pedagogical Options for Teaching Research Methods in LIS. Journal of Education for Library and Information Science, 59(3), 26-40. Retrieved from https://search-ebscohostcom.proxy.ulib.uits.iu.edu/login.aspx?direct $=$ true $\& \mathrm{db}=$ eric $\& \mathrm{AN}=\mathrm{EJ}$ $1184524 \&$ site=ehost-live

2. Bui, N.H., \& Alfaro, M. A. (2011). Statistics anxiety and science attitudes: Age, gender, and ethnicity factors. College Student Journal, 45, 573-585.

3. Burke, L., \& Rau, B. (2010). The Research-Teaching Gap in Management. Academy of Management Learning \& Education,9(1), 132-143. Retrieved from http://www.jstor.org/stable/25682438

4. Council on Social Work Education. (2015). Educational policy and accreditation standards. Alexandria, VA: Author.

5. Cronbach, L. J. (1951). Coefficient alpha and the internal structure of tests. Psychometrika, 16, 297-334.

6. Dobozy, E. (2011). Constrained by ideology: Attitudinal barriers to undergraduate research in Australian teacher education. (Report). eJournal of Business Education and Scholarship Teaching, 5(2), 36-48.

7. Dunn, D. S., McCarthy, M. A., Baker, S., Halonen, J. S., \& Hill IV, G. W. (2007). Quality benchmarks in undergraduate psychology programs. American Psychologist, 62, 650-670.

8. Howard, C., \& Brady, M. (2015). Teaching social research methods after the critical turn: challenges and benefits of a constructivist pedagogy. International Journal of Social Research Methodology, 
$18(5)$ $511-525$. https://doiorg.proxy.ulib.uits.iu.edu/10.1080/13645579.2015.1062625

9. Hsiao, T-Y., \& Chiang, S. (2011). Gender differences in statistics anxiety among graduate students learning English as a foreign language. Social Behavior and Personality, 39, 41-42.

10. Lave, J. (1988). Cognition in Practice: Mind, mathematics, and culture in everyday life. Cambridge, UK: Cambridge University Press.

11. Lave, J., \& Wenger, E. (1991). Situated Learning: Legitimate Peripheral Participation. Cambridge, UK: Cambridge University Press.

12. Linneman, J. A. (2019). Share, Show, and Tell: Group Discussion or Simulations versus Lecture Teaching Strategies in a Research Methods Course. Teaching Sociology, 47(1), 22-31. Retrieved from https://search-ebscohostcom.proxy.ulib.uits.iu.edu/login.aspx ?direct $=$ true $\& d b=$ eric $\& A N=E J$ $1201018 \&$ site $=$ ehost-live

13. Meltzoff, J., \& Cooper, H. (2018). Critical thinking about research: Psychology and related fields (2nd ed.). American Psychological Association. https://doi.org/10.1037/0000052-000

14. Messer, W. S., Griggs, R. A., \& Jackson, S. L. (1999). A national survey of undergraduate psychology degree options and major requirements. Teaching of Psychology, 26, 164-171.

15. Ponnuswami, I., \& Harris, N. (2017). Teaching research methods to social work students in India and Australia: reflections and recommendations. Social Work Education, 36(6), 690-701. https://doiorg.proxy.ulib.uits.iu.edu/10.1080/02615479.2017.1335299

16. Profetto-McGrath, J., Hesketh, K. L., Lang, S., \& Estabrooks, C. A. (n.d.). (2003). A Study of Critical Thinking and Research Utilization Among Nurses. Retrieved from https://journals.sagepub.com/doi/abs/10.1177/0193945902250421

17. Rowan, D., Richardson, S. \& Long, D. D. (2018). Practice-Informed Research: Contemporary Challenges and Ethical Decision-Making. Journal of Social Work values and Ethics, 15(2), 15-22

18. Skinner, J. \& Gilbert, K. (2007). Sport management education: teaching and learning for the future. Sport Management Review, 10(2), 125-131

19. Sells, S. P., \& And Others. (1997). Teaching Ethnographic Research Methods in Social Work: A Model Course. Journal of Social Work Education, 33,167-84. Retrieved from https://search-ebscohostcom.proxy.ulib.uits.iu.edu/login.asp $x$ ?direct $=$ true $\& d b=e r i c \& A N=E J$ 539594\&site=ehost-live 
20. Steele, C. M. (1997). A threat in the air: How stereotypes shape intellectual identity and performance. American Psychologist, 52(6), 613-629.

21. Ware, M. E., \& Davis, S. F. (1997). Student Publications Enhance Teaching: Experimental Psychology and Research Methods Courses. Retrieved from https://search-ebscohostcom.proxy.ulib.uits.iu.edu/login.aspx?direct=true $\& d b=$ eric $\& A N=E D$ 419195\&site $=$ ehost-live

22. Wenger, E. (1998). Communities of practice: Learning, meaning and identity, Cambridge: Cambridge University Press. 